\title{
Diet, sexual dimorphism and reproduction of sympatric racers Philodryas aestiva and Philodryas patagoniensis from the coastal Brazilian Pampa
}

\author{
FERNANDO M. QUINTELA and DANIEL LOEBMANN \\ Laboratório de Vertebrados, Instituto de Ciências Biológicas, Universidade Federal do Rio \\ Grande, Avenida Itália, s/n, Vila Carreiros, 96203-900 Rio Grande, RS, Brazil \\ Manuscript received on March 20, 2018, accepted for publication on July 9, 2018
}

\begin{abstract}
How to cite: QUINTELA FM AND LOEBMANN D. 2019. Diet, sexual dimorphism and reproduction of sympatric racers Philodryas aestiva and Philodryas patagoniensis from the coastal Brazilian Pampa. An Acad Bras Cienc 91: e20180296. 10.1590/0001-3765201920180296.

Abstract: Herein we investigated diet, sexual dimorphism and reproductive biology of two sympatric congeneric species at the coastal Brazilian Pampa, Philodryas aestiva and P. patagoniensis. Analysis of the stomach content of the scansorial Philodryas aestiva revealed that it feeds mainly on Anura and small mammals, while it occasionally consumes Insecta, Squamata and Aves. The more terrestrial Philodryas patagoniensis presented a broader diet, composed mainly of Anura, Squamata and small mammals. Insecta and Actinopterygii were found in lower frequencies. In females of both species, snout-vent length was significantly larger than in males, while tail length/snout-vent length ratio was significantly higher in males. Males reach sexual maturity at smaller sizes than females in both species. Fecundity was higher in P. patagoniensis ( 3 to 24 eggs; $15 \pm 8.15$ ) than in $P$. aestiva (10 to 20 eggs; $\mathrm{X}=14.50 \pm 3.53$ ). Females of $P$. aestiva showed secondary follicles in all seasons while eggs occurred from middle-winter to early-summer. Secondary follicles occurred throughout the year in P. patagoniensis, but concentrated in spring. Eggs occurred in late-summer, middle-autumn and spring. Both species presented positive correlations between SVL and clutch size. Differences in analyzed traits seem to reflect divergences in species morphology and use of habitat/microhabitat.
\end{abstract}

Key words: feeding habits, natural history, Neotropical snakes, fecundity, reproductive cycle.

\section{INTRODUCTION}

Data on natural history of snakes are crucial to understand ecological processes at community level and for species conservation (Greene 1993, Shine 1995). Particularly, studies concerning closely related (e.g. congeneric species) in sympatry have a high potential to unveil mechanisms of resource partitioning and distinct life strategies adopted by

Correspondence to: Fernando Marques Quintela

E-mail: fmquintela@yahoo.com.br

ORCid: http://orcid.org/0000-0002-8652-0642 the species (Carpenter 1952, Goodyear and Pianka 2008). For instance, studies on dietary data of closely related sympatric species could shed light on their foraging strategies, and therefore on how they partition their resources. Also, as reproduction is essential for the survival of the species, data on reproductive season and fecundity are crucial to implement management and conservation strategies (Manlik et al. 2016, Velasco et al. 2017).

The Philodryas genus comprises 23 species widely distributed in South America (Uetz et al. 2018), which presents both terrestrial and arboreal 
habits (Cacciali et al. 2016). They are commonly known as "racers" due to their capacity for rapid displacement and slender body. In the southernmost Brazilian coast, which belongs to the Pampa biome, three species of Philodryas occur sympatrically in open habitats of grasslands and savannas: the Green Racer Philodryas aestiva (Duméril, Bibron \& Duméril, 1854), the Patagonian Racer Philodryas patagoniensis (Girard, 1857) and the Lichtenstein's Green Racer Philodryas olfersii (Lichtenstein, 1823). The first two species are commonly found in open environments while the latter is mostly associated with forest formations (Quintela and Loebmann 2009). Comparatively, P. patagoniensis is more robust, terrestrial and attains greater sizes than $P$. aestiva, which in turn is a typical scansorial species, with a slender body and long and prehensile tail (Lema 2002) (Fig. 1). In the southernmost Brazilian coast, Philodryas patagoniensis also occupies a greater variety of habitats, including flooded and xerophytic environments (such as the interior of marshes, saltmarshes and coastal dunes) where $P$. aestiva is apparently absent (Quintela and Loebmann 2009). Aspects of the natural history of $P$. patagoniensis have been examined in several areas along its distribution (Vaz-Ferreira et al. 1970, Carreira-Vidal 2002, Pontes et al. 2003, Hartmann and Marques 2005, López and Giraudo 2008, Sawaya et al. 2008, Marques et al. 2012, NetoSilva et al. 2012, Loebens et al. 2016, 2017, Ucha and Santos 2017) but data are still lacking from the southernmost Brazilian coast. As for P. aestiva, dietary data is scarce (Carreira-Vidal 2002, França et al. 2008) and there are no studies addressing reproduction and sexual dimorphism in the species.

Given the distinct morphology and habits of the sympatric $P$. patagoniensis and $P$. aestiva, the aim of this study was to investigate and compare the feeding habits, sexual dimorphism and reproductive biology from a sample of specimens from the open areas of coastal Brazilian Pampa. In view of previous studies (Hartmann and Marques 2005, Pizzatto et
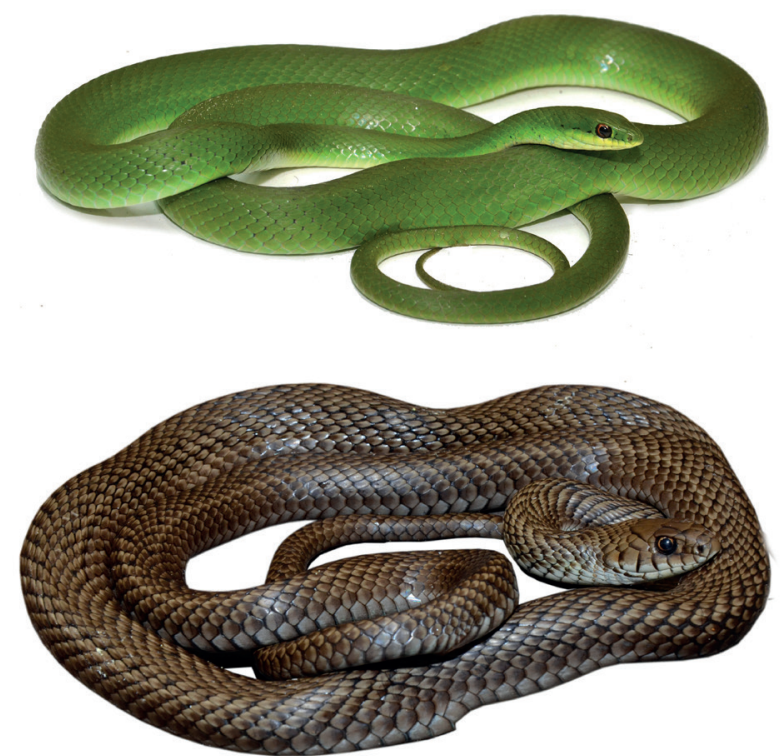

Figure 1 - Philodryas aestiva (upper image) and Philodryas patagoniensis (bottom image) from the Brazilian coastal Pampa, Rio Grande do Sul state (photographed by Daniel Loebmann).

al. 2007, 2008), we expect that differences in size and habits will reflect in divergences on the aspects of feeding and reproductive biology between the species. It is assumed that $P$. aestiva explores more scansorial prey and presents lower fecundity than P. patagoniensis.

\section{MATERIALS AND METHODS}

\section{STUDY AREA}

We examined specimens collected along a stretch of ca. $500 \mathrm{~km}$ of the coastal plain of the state of Rio Grande do Sul, southernmost Brazil, between the municipalities of Cidreira (30 $07^{\circ} 30^{\prime}$ 'S;

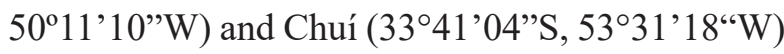
(Appendix; Fig. 2). The study area is nested in the Pampa biome and presents a temperate humid climate according to the regional classification by Maluf (2000). Seasons are well-defined and rainfall $(1,600 \mathrm{~mm}$ in average $)$ is concentrated mainly in the winter and spring (Vieira 1984, Maluf 2000). Specimens were collected in grasslands 


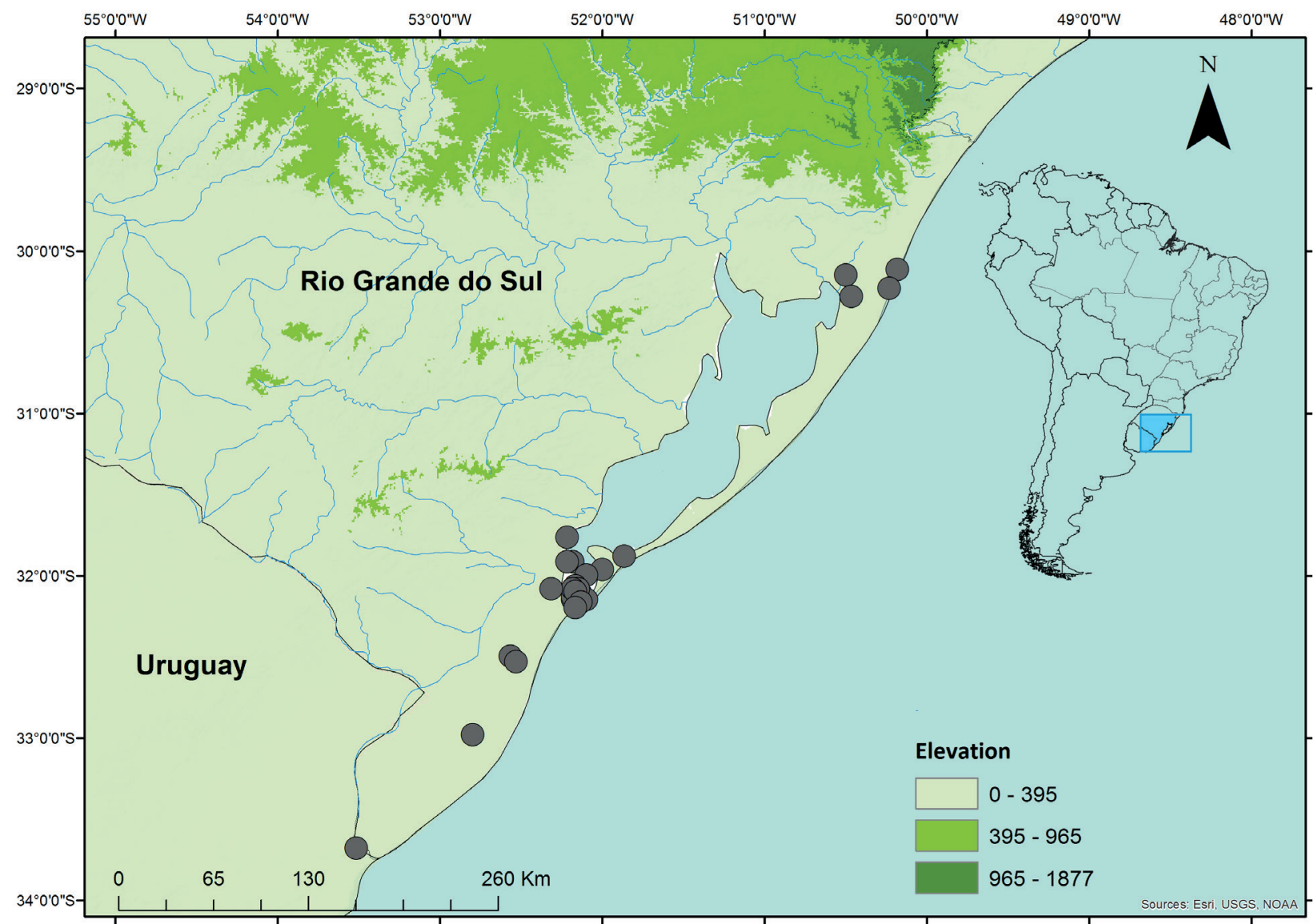

Figure 2 - Location of the sampled sites at southernmost Brazilian coast, Rio Grande do Sul state.

(predominantly gramineous/herbaceous) and humid savannas (predominantly herbaceous/ arbustive, with sparse trees), the most representative vegetation types in the region. Specimens are housed in the herpetological collection of Universidade Federal do Rio Grande (CHFURG), Rio Grande municipality, Rio Grande do Sul, Brazil. All procedures were carried out according to the international practices for animal use and care under the control of an internal committee of the Universidade Federal do Rio Grande, Brazil.

\section{DIET}

We examined a total of 79 specimens of $P$. aestiva (45 females and 34 males) and 126 specimens of P. patagoniensis ( 75 females and 51 males). The digestive and reproductive tracts were externalized for analysis through a ventral incision made from the esophageal region to around $5 \mathrm{~mm}$ above the cloaca. All stomach and gut contents were removed and identified to the lowest possible taxonomic category. The frequency of occurrence of each identified taxon (FO\%) was determined as the ratio between the number of tracts containing one specific taxon and the total number of analyzed tracts. The numeric abundance index (N\%) of each identified taxon was calculated as the absolute number of prey items from one specific taxon divided by the sum of prey items of all identified taxa (Corrêa et al. 2016). Stomach and gut content was also classified in prey categories according to broad taxonomic categories, as follows: 1) Arthropoda, 2) Actinopterygii, 3) Amphibia, 4) Squamata, 5) Aves, 6) Mammalia. FO\% of each 
prey type was determined as the ratio between the number of tracts containing one specific prey type and the total number of analyzed tracts. N\% of each prey type was calculated as the absolute number of prey items from one specific prey type divided by the sum of prey items of all prey types.

\section{SEXUAL DIMORPHISM AND REPRODUCTION}

The following measures were taken from each specimen: snout-vent length (SVL), tail length (TL), tail proportion in relation to SVL (ratio TL/ SVL). The sex was determined by the presence or absence of the hemipenis via subcaudal incision. To determine the presence of sexual dimorphism, for each species we examined differences in SVL and in ratio TL/SVL between males and females with a $t$ test (Quintela et al. 2017). For both species, the Sexual Size Dimorphism (SSD) index was calculated according to Gibbons and Lovich (1990), where SSD = mean SVL of the larger sex divided by the mean SVL of the smaller sex. Negative values of SSD indicate that males are larger than females.

The following data were taken from females: total number of ovarian follicles; number of secondary follicles (follicles in secondary vitellogenesis); largest diameter of the largest secondary follicle; total number of eggs; largest diameter of the largest egg. The initial diameter of secondary follicles was determined based on coloration; primary follicles differ conspicuously from secondary follicles due to their darker yellow coloration (see Almeida-Santos et al. 2014). Females were considered as sexually mature when showing at least one of the following characteristics: secondary follicles; oviductal eggs; folded oviducts, indicating recent oviposition (Mesquita et al. 2013). Males were considered sexually mature when presenting coiled and opaque ductus deferens, indicating the presence of sperm (Shine 1977, Almeida-Santos et al. 2014). The female reproductive cycle was evaluated based on the the annual profile resultant from the plot of the largest follicles and eggs of each female (Mesquita et al. 2013, Almeida-Santos et al. 2014). Fecundity was determined by the number of eggs in the oviduct (real fecundity; clutch size) and number of secondary follicles (potential fecundity) (Mesquita et al. 2013). The existence of significant differences in real fecundity between the two species was examined through a $t$ test. The relationship between female SVL and real fecundity (clutch size) was examined through a simple linear regression analysis (Siqueira et al. 2013).

\section{RESULTS}

DIET

Nineteen out of the 79 specimens of $P$. aestiva (24\% of sample) presented 31 prey items in their digestive tracts, which corresponded to 11 identified taxa. Of these, thirteen specimens contained a single item. Two specimens presented two and three items from distinct taxa, as follows: (1) unidentified Aves, unidentified Squamata; (2) unidentified Squamata, Orthoptera and Coleoptera. Four specimens presented more than one item from the same species, which include: (1) remains of two Dendropsophus minutus (Anura: Hylidae) specimens; (2) remains of three specimens of Boana pulchella (Anura: Hylidae); (3) three Oligoryzomys sp. (Rodentia: Sigmodontinae) neonates; (4) five Oligoryzomys sp. neonates.

Forty-seven $P$. patagoniensis specimens (37.3\% of samples) presented 53 prey items in their digestive tracts, comprising 23 identified taxa. Forty-three specimens contained a single item. Four specimens presented two items from distinct taxa, including: (1) Physalaemus biligonigerus (Anura: Leptodactylidae) and one unidentified small mammal; (2) Helicops infrataeniatus and P. patagoniensis (Squamata: Dipsadidae); (3) Leptodactylus latrans (Anura: Leptodactylidae) 
and Cercosaura schreibersii (Squamata: Gymnophthalmidae); (4) unidentified Anura and Belostomatidae. One specimen presented three adult dipterans. Absolute number, FO\% and $\mathrm{N} \%$ of all identified taxa, for both snake species, are shown in Table I. Absolute number, FO\% and $\mathrm{N} \%$ of prey categories, for both snake species, are shown in bold in Table I.

\section{SEXUAL DIMORPHISM AND REPRODUCTION}

Females of $P$. aestiva $(\mathrm{n}=45)$ presented significantly larger SVL than males $(\mathrm{n}=34)(t=-4.197 ; P<0.0001)$ while males presented significantly higher TL/ SVL ratios than females $(t=13.527 ; P<0.0001)$. Similarly, females of $P$. patagoniensis $(\mathrm{n}=75)$ presented significantly larger SVL than males $(\mathrm{n}=51)(t=5.150 ; P<0.0001)$ while males showed significantly higher TL/SVL ratios than females $(t=-12.180 ; P<0.0001)$. However, an overlap in
TL/SVL ratios between sexes was observed in both species, this being more pronounced in $P$. patagoniensis (Table II). Mean, standard deviation and range of SVL and TL/SVL for males and females of both species are shown in Table II. The SSD index was 1.269 for P. aestiva and 1.374 for P. patagoniensis, confirming that females are larger than males in both species.

The SVL of $P$. aestiva mature females varied from 630 to $835 \mathrm{~mm}(X=731.36 \pm 76.67 \mathrm{~mm})$ while SVL of mature males ranged from 383 to 572 $\mathrm{mm}(X=487.61 \pm 44.71 \mathrm{~mm})$. Mature females of $P$. patagoniensis presented SVL varying from 719 to $1076 \mathrm{~mm}(X=894.56 \pm 121.10 \mathrm{~mm})$ while $\mathrm{SVL}$ in mature males varied from 453 to $786 \mathrm{~mm}(X=$ $637.93 \pm 97.80 \mathrm{~mm})$. Thus, females reach sexual maturity at greater sizes than males in both species.

Females of $P$. aestiva showed primary and secondary follicles in all seasons while oviductal

TABLE I

Absolute number (AN), frequency of occurrence (FO\%) and numeric abundance index (N\%) of each taxon identified in digestive tracts of Philodryas aestiva and Philodryas patagoniensis from the Brazilian coastal Pampa, Rio Grande do Sul state.

\begin{tabular}{|c|c|c|c|c|c|c|}
\hline \multirow[t]{2}{*}{ Prey taxon } & \multicolumn{3}{|c|}{ Philodryas aestiva } & \multicolumn{3}{|c|}{ Philodryas patagoniensis } \\
\hline & $\mathbf{A N}$ & FO\% & N\% & $\mathbf{A N}$ & FO\% & N\% \\
\hline Arthropoda & 2 & 5.26 & 6.45 & 4 & 4.65 & 7.54 \\
\hline Coleoptera & 1 & 5.26 & 3.22 & & & \\
\hline Diptera & & & & 3 & 2.13 & 5.66 \\
\hline Orthoptera & 1 & 5.26 & 3.22 & & & \\
\hline \multicolumn{7}{|l|}{ Hemiptera } \\
\hline Belostomatidae & & & & 1 & 2.13 & 1.88 \\
\hline \multicolumn{7}{|l|}{ Vertebrata } \\
\hline Actinopterygii & & & & 1 & 2.13 & 1.88 \\
\hline \multicolumn{7}{|l|}{ Erythrinidae } \\
\hline Hoplias malabaricus & & & & 1 & 2.13 & 1.88 \\
\hline Amphibia & 10 & 38.64 & 32.25 & 20 & 48.83 & 36.62 \\
\hline \multicolumn{7}{|l|}{ Hylidae } \\
\hline Boana pulchella & 5 & 15.79 & 16.13 & & & \\
\hline Dendropsophus minutus & 2 & 5.26 & 6.45 & & & \\
\hline unidentified Hylidae & & & & & & \\
\hline
\end{tabular}


TABLE I (continuation)

\begin{tabular}{|c|c|c|c|c|c|c|}
\hline \multirow[t]{2}{*}{ Prey taxon } & \multicolumn{3}{|c|}{ Philodryas aestiva } & \multicolumn{3}{|c|}{ Philodryas patagoniensis } \\
\hline & AN & FO\% & $\mathrm{N} \%$ & $\mathbf{A N}$ & FO\% & N\% \\
\hline \multicolumn{7}{|l|}{ Leptodactylidae } \\
\hline Physalaemus biligonigerus & & & & 1 & 2.13 & 1.88 \\
\hline Physalaemus gracilis & 1 & 5.26 & 3.22 & 1 & 2.13 & 1.88 \\
\hline Leptodactylus latrans & & & & 11 & 23.40 & 20.74 \\
\hline \multicolumn{7}{|l|}{ Bufonidae } \\
\hline Rhinella fernandezae & & & & 1 & 2.13 & 1.88 \\
\hline unidentified Anura & 2 & 10.52 & 6.45 & 6 & 12.76 & 11.32 \\
\hline Squamata & 2 & 10.52 & 6.45 & 16 & 34.88 & 30.18 \\
\hline \multicolumn{7}{|l|}{ Gymnophthalmidae } \\
\hline Cercosaura schreibersii & & & & 4 & 8.51 & 7.54 \\
\hline \multicolumn{7}{|l|}{ Anguidae } \\
\hline Ophiodes aff. striatus & & & & 2 & 4.25 & 3.77 \\
\hline \multicolumn{7}{|l|}{ Serpentes: Dipsadidae } \\
\hline Erythrolamprus semiaureus & & & & 1 & 2.13 & 1.88 \\
\hline Helicops infrataeniatus & & & & 2 & 4.25 & 3.77 \\
\hline Oxyrhopus rhombifer & & & & 2 & & 3.77 \\
\hline Philodryas patagoniensis & & & & 1 & 2.13 & 1.88 \\
\hline Xenodon dorbignyi & & & & 1 & 2.13 & 1.88 \\
\hline unidentified Dipsadidae & & & & 1 & 2.13 & 1.88 \\
\hline unidentified Squamata & 2 & 10.52 & 6.45 & 2 & 4.25 & 3.77 \\
\hline Aves & 1 & 5.26 & 3.22 & & & \\
\hline Mammalia & 16 & 52.63 & 51.61 & 9 & 20.93 & 16.98 \\
\hline \multicolumn{7}{|l|}{ Rodentia: Cricetidae } \\
\hline Deltamys kempi & & & & 1 & 2.13 & 1.88 \\
\hline Holochilus vulpinus & & & & 1 & 2.13 & 1.88 \\
\hline Oligoryzomys sp. & 8 & 10.52 & 25.80 & & & \\
\hline unidentified Rodentia & 2 & 10.52 & 6.45 & 1 & 2.13 & 1.88 \\
\hline unidentified Mammalia & 6 & 31.57 & 19.35 & 6 & 12.76 & 11.32 \\
\hline unidentified Vertebrata & & & & 3 & 6.38 & 5.66 \\
\hline
\end{tabular}

eggs were found from middle-winter to earlysummer. Females of $P$. patagoniensis presented primary and secondary follicles in all seasons, with a higher concentration of the later during spring. Oviductal eggs in $P$. patagoniensis were found sparsely in late-summer, middle-autumn and spring (Fig. 3). In both species, follicles that presented the characteristics of secondary vitellogenesis had approximately $9 \mathrm{~mm}$ of diameter.

Real fecundity (clutch size) in $P$. aestiva varied from 10 to $20(X=14.50 \pm 3.53)$ while potential fecundity ranged from 2 to $14(X=9.60 \pm 4.61)$. The smallest $P$. aestiva female with primary follicles presented $305 \mathrm{~mm}$ of SVL. The SVL of 
TABLE II

Values of means $(X)$, standard deviation (sd) and range of the variables analyzed in Philodryas aestiva and Philodryas patagoniensis from the Brazilian coastal Pampa, Rio Grande do Sul state (SVL= snout-vent length; TL/SVL = tail proportion in relation to SVL).

\begin{tabular}{ccccccc}
\hline Variable & \multicolumn{3}{c}{ Philodryas aestiva } & \multicolumn{2}{c}{ Philodryas patagoniensis } \\
\hline & $\boldsymbol{X}$ & sd & Range & $\boldsymbol{X}$ & sd & Range \\
\cline { 2 - 7 } SVL males & 453.96 & 82.02 & $227-572$ & 546.17 & 176.09 & $190-786$ \\
SVL females & 576.38 & 169.38 & $305-835$ & 750.92 & 243.80 & $230-1076$ \\
TL/SVL males & 0.492 & 0.023 & $0.435-0.539$ & 0.400 & 0.033 & $0.300-0.461$ \\
TL/SVL females & 0.407 & 0.026 & $0.355-0.470$ & 0.321 & 0.034 & $0.217-0.385$ \\
\hline
\end{tabular}

the smallest $P$. aestiva female carrying secondary follicles and oviductal eggs was 630 and 659 $\mathrm{mm}$, respectively. A positive correlation (but not significant) was detected between clutch sizes and SVL of $P$. aestiva females $(r=0.752 ; P=0.084)$. Females of $P$. patagoniensis showed real fecundity varying from 3 to $24(X=15 \pm 8.15)$ while potential fecundity ranged from 3 to $32(X=13.43 \pm 7.48)$. The smallest $P$. patagoniensis female carrying primary follicles presented $362 \mathrm{~mm}$ of SVL. The SVL of the smallest $P$. patagoniensis female carrying secondary follicles and oviductal eggs was 752 and 719, respectively. A positive but not significant correlation was found between clutch sizes and SVL of $P$. patagoniensis females $(r=$ 0.592; $P=0.292$ ). No significant difference was found in real fecundity between the two species $(t$ $=0.270 ; P=0.793)$.

\section{DISCUSSION}

\section{DIET}

The present study adds to previous evidence that implies that both $P$. patagoniensis and $P$. aestiva are generalists, although the former seems to feed on a broader range of prey (greater variety of species within a category). The diet of $P$. aestiva consisted basically of small mammals and anurans, with occasional occurrences of Coleoptera, Orthoptera and birds. Insects, however, occurred in association

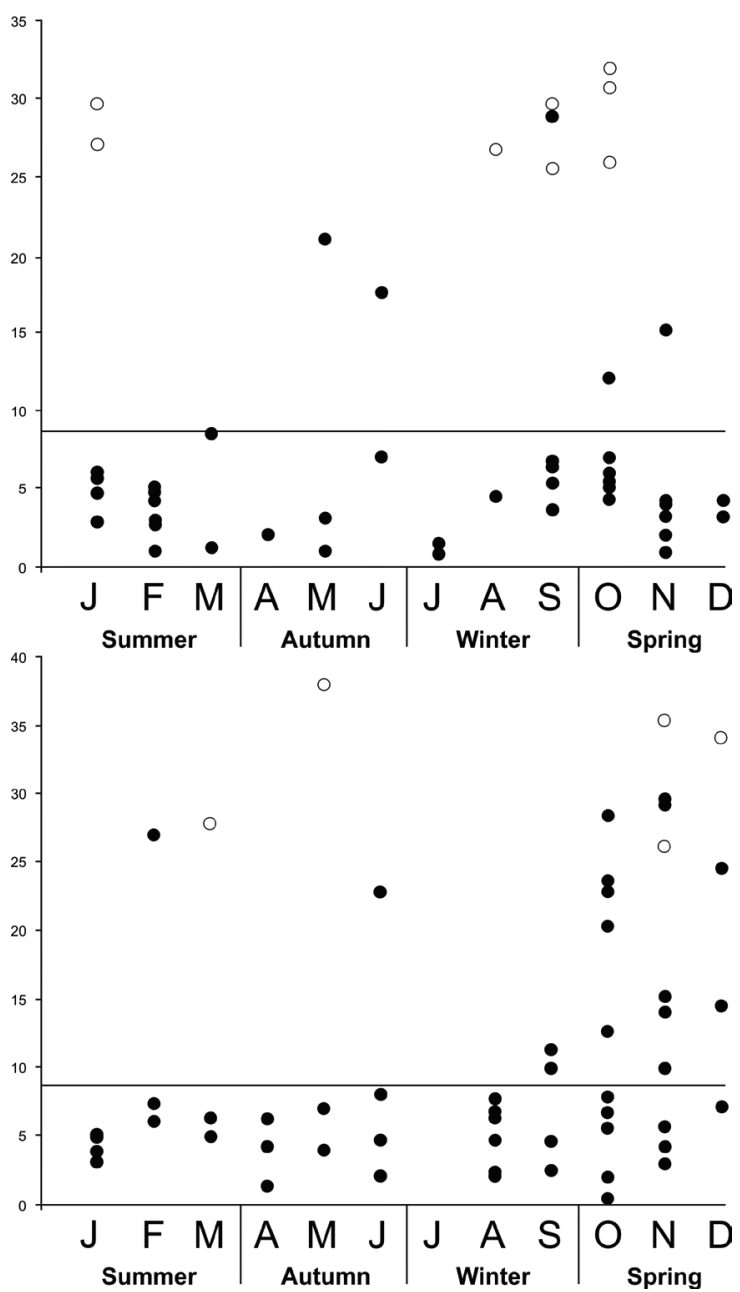

Figure 3 - Monthly variation in diameter $(\mathrm{mm})$ of the largest follicles (black circles) and eggs (white circles) of Philodryas aestiva (upper image) and Philodryas patagoniensis (bottom image) from the Brazilian coastal Pampa, Rio Grande do Sul state. The horizontal line represents the length of the largest axis from which the follicles are considered in secondary vitellogenesis $(9 \mathrm{~mm})$. 
with the remains of one unidentified Squamata and may represent secondary items (items consumed by the squamate prey). Philodryas patagoniensis, in turn, feeds on a wide spectrum which includes anurans, lizards, snakes (including cannibalism), small mammals, and occasionally insects (belostomatid Hemiptera and adult Diptera) and the fish Hoplias malabaricus. Amphibians, however, were the most frequently consumed items, as well as in other populations studied in southern Brazil (Hartmann and Marques 2005) and Uruguay (Carreira-Vidal 2002). López and Giraudo (2008), in contrast, found the predominance of reptiles in samples from northeast Argentina, suggesting the occurrence of a geographic variation in $P$. patagoniensis dietary pattern, probably triggered by prey availability. According to these authors, Brazilian and Uruguayan populations prey mostly on amphibians while the populations from Argentina consume more reptiles relative to other vertebrate groups. Therefore, our findings corroborate this pattern. The belostomatid found in P. patagoniensis was associated with the anuran Leptodactylus latrans and was probably preyed by the amphibian, but adult dipterans (three specimens), interestingly, were found unassociated in the analyzed tract. Diptera and fish are herein reported for the first time in the diet of $P$. patagoniensis. All other types of prey found in our $P$. aestiva and $P$. patagoniensis samples have already been recorded in literature (Carreira-Vidal 2002, Pontes et al. 2003, Hartmann and Marques 2005, López and Giraudo 2008, Marques et al. 2012, Neto-Silva et al. 2012). Carreira-Vidal (2002) also reports small lizards and bats in the diet of $P$. aestiva from the Uruguayan Pampa while França et al. (2008) mentions the medium-sized teiid Ameiva ameiva as $P$. aestiva prey in Cerrado areas of central Brazil. The similar size of Oligoryzomys sp. neonates in each $P$. aestiva tract also indicates predation on rodent litters. Other types of prey recorded in the diet of P. patagoniensis but not found in our sample were ants (Carreira-
Vidal 2002, López and Giraudo 2008), Coleoptera (Neto-Silva et al. 2012), Orthoptera (López and Giraudo 2008), spiders of the Lycosa genus (Carreira-Vidal 2002), birds (Carreira-Vidal 2002, Hartmann and Marques 2005, Ucha and Santos 2017) and Leporidae (Pontes et al. 2003). All these items can also occur in the diet of $P$. patagoniensis from our study area, considering its availability. Cases of cannibalism by $P$. patagoniensis have already been reported in other pampean areas of northern and central Rio Grande do Sul (Pontes et al. 2003) and Uruguay (Carreira-Vidal 2002).

There still are controversies about the factors shaping divergences between dietary patterns of closely related snake species. Colston et al. (2010) demonstrated that a deep divergence in the evolutionary history of Serpentes (Scolecophidia/ Alethinophidia divergence, occurred during the early Cretaceous, approximately 110 Mya [Hsiang et al. 2015]) was responsible for most of the dietary shift in the group while divergences within the advanced snake's clade (Alethinophidia), occurred during late Cretaceous and Eocene (approximately 81-50 Mya) (Hsiang et al. 2015), had few effects in the diversification of diet as a whole. Thus, divergences in dietary patterns of closely-related species can be attributed to effects of habitat, microhabitat and behavior (Colston et al. 2010). The expected differences in diet composition of the two sympatric Philodryas in the present study may be a result of divergence in their use of habitat and microhabitat by the distinct species. So, this can consist in an example of niche evolution, a condition when closely related species adopt distinct ecological strategies which permit its coexistence (Ackerly et al. 2006). Hartmann and Marques (2005) also found differences in diet composition between scansorial $P$. olfersii and P. patagoniensis from the northern Pampa in Rio Grande do Sul and attributed such differences to divergences in foraging microhabitat use by the species. The occurrence of hylids and one bird in 
our $P$. aestiva sample reflects its scansorial habits. Philodryas patagoniensis, typically terrestrial and also associated to flooded environments, showed high representativeness of terrestrial anurans, lizards and snakes in its diet, as well as the occurrence of fish and rodents associated to humid/flooded habitats (Deltamys kempi and Holochilus vulpinus). However, hylids were absent in digestive tracts of $P$. patagoniensis of the present study. Hylids were also absent in the diet of $P$. patagoniensis from northeastern Argentina (López and Giraudo 2008), where terrestrial anurans (Bufonidae and Leptodactylidae) composed all amphibian prey. Carreira-Vidal (2002) and Hartmann and Marques (2005) found hylids in the diet of $P$. patagoniensis from Uruguay and from the northern Brazilian Pampa respectively, but at much lower abundance and frequency when compared to terrestrial anurans. Considering our data and all the aforementioned studies, it is plausible that $P$. patagoniensis feeds mainly on terrestrial stratum and occasionally in aquatic environments while $P$. aestiva explores both arbustive/arboreal and terrestrial stratum. This divergence in foraging habits may represent a conditioning factor for the occurrence of these species in sympatry.

\section{SEXUAL DIMORPHISM AND REPRODUCTION}

In both studied Philodryas species, females attained greater body sizes than males, which agrees with observations of $P$. patagoniensis from northern Argentina and southern Brazil (López and Giraudo 2008, Loebens et al. 2017) and other xenodontines (see Aguiar and Di-Bernardo 2005, Ávila et al. 2006, Zanella and Cechin 2010, Prieto et al. 2012, Mesquita et al. 2013, Panzera and Maneyro 2013, Quintela et al. 2017). Males of both Philodryas species presented significantly higher TL/SVL ratios than females, but due to the overlapped range observed between sexes within both species, the character can not be considered absolutely dimorphic. The tail in males accommodates the hemipenis and retracting muscles (King 1989), thus, higher TL/SVL proportions are usually expected for males. However, the fact that $P$. patagoniensis showed more range overlap when compared to $P$. aestiva was not expected, considering that dimorphism in tail size is discrete or even absent in species with a certain degree of arboreality (Pizzatto et al. 2008), which is the case of the latter.

Females of both Philodryas species presented eggs and secondary follicles in both the warmer and colder seasons of the year. In P. aestiva, eggs were restricted to the period from middle-winter to early summer, which indicates that the female reproductive cycle in the species may follow a seasonal pattern. However, analyzes of a larger sample are needed to draw further conclusions. The occurrence of eggs in P. patagoniensis euthanized in late-summer and middle-autumn contradicts the previous data on the female reproductive cycle in the species, considered seasonal. López and Giraudo (2008) found eggs from October (earlyspring) to January (early-summer) in samples from southern Argentina. Loebens et al. (2017), analyzing populations from a large portion of southern Brazil (states of Paraná, Santa Catarina and north and central Rio Grande do Sul), reported the presence of eggs from August (middle-winter) to February (middle-summer). In our $P$. patagoniensis sample, higher concentrations of secondary follicles and eggs in the spring supports a seasonal trend, but the occurrence of eggs in middle-autumn dissociates from the pattern. Thus, P. patagoniensis females may exhibit plasticity in reproductive cycles possibly conditioned by local environmental factors, which has already been verified in other widespread xenodontine species (see Pizzatto and Marques 2006, Quintela et al. 2017).

In accordance with our expectations, due to $P$. patagoniensis larger size, this species presented greater fecundity when compared to $P$. aestiva. Morphological adaptations to arboreality such as 
slender bodies and reduction of the body cavity, as a result of improved proportionality of the tail in relation to body length, act as limiting factors in the development of great clutch sizes (Pizzatto et al. 2007). However, real fecundity in our $P$. aestiva sample was greater than that recorded in arboreal P. olfersii (4 to 11 eggs; Mesquita et al. 2013), considering that the later reaches considerably larger body lengths. This fact may be due to the conspicuous smaller size of $P$. aestiva eggs in relation to P. olfersii eggs (Mesquita et al. 2013; present study), so that a larger number of eggs can develop in the former. The positive correlation between female SVL and fecundity in $P$. aestiva was also expected, since larger females are able to develop larger clutches (Shine 1994). In $P$. patagoniensis, the observed fecundity is similar to that found in other studied regions (López and Giraudo 2008, Loebens et al. 2017). The positive correlation between female SVL and fecundity in our analyzed sample also corroborates the pattern detected in other investigated populations (López and Giraudo 2008, Loebens et al. 2017). However, unlike the results of López and Giraudo (2008) and Loebens et al. (2017), such correlation was not significant in our study.

In conclusion, the two sympatric Philodryas species herein analyzed diverge in traits of their natural history. Such divergence can be related to differences in morphology and use of habitat and microhabitat. Thus, more comparative studies are encouraged, aiming to clarify distinct aspects of the biology and ecology of sympatric congeneric/ closely related species.

\section{ACKNOWLEDGMENTS}

We thank the Coordenação de Aperfeiçoamento de Pessoal de Nível Superior (CAPES) for the postdoctoral fellowship granted to the first author; Victor H.S. Teixeira, Omar M. Entiauspe-Neto, Andressa M. Gomide, Pablo M. Borges, Ruth
A. Regnet, Franck L. Silveira and Rafael A. Porciuncula for the help in fieldwork and laboratory procedures; Arthur Abegg for drawing the map; Rebeca Alves for language review; ICMBio environmental agency for the permission to collect (proc. 43658).

\section{AUTHOR CONTRIBUTIONS}

FMQ: Contribution to concept and design of the study, data collection and manuscript preparation. DL: Contribution to concept and design of the study, data collection and critical review of the manuscript.

\section{REFERENCES}

ACKERLY DD, SCHWILK DW AND WEBB CO. 2006. Niche evolution and adaptative radiation: testing the order of trait divergence. Ecology 87: 50-61.

AGUIAR LFS AND DI-BERNARDO M. 2005. Reproduction of the water snake Helicops infrataeniatus (Colubridae) in southern Brazil. Amphibia-Reptilia 26: 527-533.

ALMEIDA-SANTOS SM, BRAZ HBP, SANTOS LC, BARROS VA, ROJAS CA AND KASPEROVICZUS KN. 2014. Biologia reprodutiva de serpentes: recomendações para a coleta e análise de dados. Herpetol Bras 3: 14-24.

ÁVILA RW, FERREIRA VL AND ARRUDA JAO. 2006. Natural History of the South American Water Snake Helicops leopardinus (Colubridae: Hydropsini) in the Pantanal, Central Brazil. J Herpetol 40: 274-279.

CACCIALI P, CABRAL H, FERREIRA VLAND KÖHLER G. 2016. Revision of Philodryas mattogrossensis with the revalidation of P. erlandi (Reptilia: Squamata: Dipsadidae). Salamandra 52: 293-304.

CARPENTER CC. 1952. Comparative ecology of the Common Garter Snake (Thamnophis s. sirtalis), the Ribbon Snake (Thamnophis s. sauritus), and Butler's Garter Snake (Thamnophis butleri) in mixed populations. Ecol Monogr 22: 235-258.

CARREIRA-VIDAL S. 2002. Alimentación de los ofidios de Uruguay. Barcelona: Associación Herpetológica Española, $127 \mathrm{p}$.

CORREA DN, QUINTELA FM AND LOEBMANN D. 2016. Feeding ecology of Erythrolamprus jaegeri jaegeri (Günter, 1858) and Erythrolamprus poecilogyrus sublineatus (Cope, 1860) in the coastal zone of Subtropical 
Brazil (Serpentes, Dipsadidae). An Acad Bras Cienc 88: 293-308.

COLSTON TJ, COSTA GC AND VITT LJ. 2010. Snake diets and the deep history hypothesis. Biol J Linnean Soc 101: 476-486.

FRANÇA FGR, MESQUITA DO, NOGUEIRA CC AND ARAÚJO AFB. 2008. Phylogeny and ecology determine morphological structure in a snake assemblage in the Central Brazilian Cerrado. Copeia 2008: 23-38.

GIBBONS JW AND LOVICH JE. 1990. Sexual dimorphism in turtles with emphasis on the slider turtle (Trachemys scripta). Herpetol Monogr 4: 1-29.

GOODYEAR SE AND PIANKA ER. 2008. Sympatric ecology of five species of fossorial snakes. J Herpetol 42: 279-285.

GREENE HW. 1993. What's good about good natural history? Herpetol Nat Hist 1: 3 .

HARTMANN PA AND MARQUES OAV. 2005. Diet and habitat use of two sympatric -species of Philodryas (Colubridae), in south Brazil. Amphibia-Reptilia 26: 25-31.

HSIANG AY, FIELD DJ, WEBSTER TH, BEHLKE ADB, DAVIS MB, RACICOT RA AND GAUTHIER JA. 2015. The origin of snakes: revealing the ecology, behavior, and evolutionary history of early snakes using genomics, phenomics, and the fossil record. BMC Evol Biol 15: 87.

KING R. 1989. Sexual dimorphism in snakes tail length: sexual selection, natural selection, or morphological constraint? Biol J Linnean Soc 38: 133-154.

LEMA T. 2002. Os répteis do Rio Grande do Sul: atuais e fósseis, biogeografia, ofidismo. Porto Alegre: EDIPUCRS, $166 \mathrm{p}$.

LOEBENS L, CECHIN SZ, THEIS TF, MOURA LB AND ALMEIDA-SANTOS SM. 2016. Reproductive biology of Philodryas patagoniensis (Snakes: Dipsadidae) in south Brazil: Male reproductive cycle. Acta Zool 98: 329-339.

LOEBENS L, ROJAS CA, ALMEIDA-SANTOS SM AND CECHIN SZ. 2017. Reproductive biology of Philodryas patagoniensis (Snakes: Dipsadidae) in south Brazil: Female reproductive cycle. Acta Zool 99: 105-114.

LÓPEZ MS AND GIRAUDO AR. 2008. Ecology of the snake Philodryas patagoniensis (Serpentes, Colubridae) from Northeast Argentina. J Herpetol 42: 474-480.

MALUF JR. 2000. Nova classificação climática do Estado do Rio Grande do Sul. Rev Bras Agromet 8: 141-150.

MANLIK O, MCDONALD JA, MANN J, RAUDINO HC, BEJDER L, KRÜTZEN M, CONNOR RC, HEITHAUS MR, LACY RC AND SHERWIN WB. 2016. The relative importance of reproduction and survival for the conservation of two dolphin populations. Ecol Evol 6: 3496-3512.

MARQUES R, TINÔCO MS, BROWNE-RIBEIRO HC, COELHO HEA AND TRAVASSOS MLO. 2012. Philodryas olfersii predation by Philodryas patagoniensis
(Serpentes: Colubridae) in the Restinga ecosystem, north coast of Bahia, Brazil. Herpetol Notes 5: 305-307.

MESQUITA PCMD, SÁ-POLIDORO GL AND CECHIN SZ. 2013. Reproductive biology of Philodryas olfersii (Serpentes, Colubridae) in a subtropical region of Brazil. Herpetol J 23: 39-44.

NETO-SILVA DA, GOUVEIA RV AND NOVELLI IA. 2012. Philodryas patagoniensis (Patagonian Green Racer). Diet Herpetol Rev 43: 349.

PANZERA A AND MANEYRO R. 2013. Reproductive biology of the snake Liophis anomalus (Günther, 1858, Dipsadidae, Xenodontinae). Herpetol J 23: 81-87.

PIZZATTO L, ALMEIDA-SANTOS SM AND SHINE R. 2007. Life-history adaptations to arboreality in snakes. Ecol 88: 359-366.

PIZZATTO L, CANTOR M, OLIVEIRAJL, MARQUES OAV, CAPOVILLA V AND MARTINS M. 2008. Reproductive ecology of dipsadine snakes, with emphasis on South American species. Herpetol 64: 168-179.

PIZZATTO LAND MARQUES OAV.2006. Interpopulational variation in reproductive cycles and activity of the water snake Liophis miliaris (Colubridae) in Brazil. Herpetol J 16: 353-362.

PONTES GMF, OLIVEIRA RB, DI-BERNARDO M AND BORGES-MARTINS M. 2003. Philodryas patagoniensis (papa-pinto). Cannibalism. Herpetol Rev 34: 154.

PRIETO YA, GIRAUDO AR AND LÓPEZ MS. 2012. Diet and sexual dimorphism of Liophis poecilogyrus (Serpentes, Dipsadidae) from the wetland regions of northeast Argentina. J Herpetol 46: 402-406.

QUINTELA FM AND LOEBMANN D. 2009. Guia ilustrado: os répteis da região costeira do extremo sul do Brasil. Pelotas: USEB, 82 p.

QUINTELA FM, MARQUES WC AND LOEBMANN D. 2017. Reproductive biology of the Green Ground Snake Erythrolamprus poecilogyrus sublineatus (Serpentes: Dipsadidae) in Subtropical Brazil. An Acad Bras Cienc 89: 2189-2197.

SAWAYA RJ, MARQUES OAV AND MARTINS M. 2008. Composição e história natural das serpentes de Cerrado de Itirapina, São Paulo, sudeste do Brasil. Biota Neotrop 8: $127-149$.

SHINE R. 1977. Reproduction in Australian elapid snakes. I. Testicular cycles and mating seasons. Aust J Zool 25: 647-653.

SHINE R. 1994. Sexual size dimorphism in snakes revisited. Copeia 1994: 326-346.

SHINE R. 1995. Australian Snakes: A Natural History. New York: Cornell University Press, p. 224.

SIQUEIRA DM, NASCIMENTO LP, MONTINGELLI GG AND SANTOS-COSTA MC. 2013. Geographical variation in the reproduction and sexual dimorphism of 
the Boddaert's tropical racer, Mastigodryas boddaerti (Serpentes: Colubridae). Zoologia 30: 475-481.

UCHA J AND SANTOS TG. 2017. Death and life on the roadway: scavenging behaviour of the green racer snake Philodryas patagoniensis (Girard, 1858) (Dipsadidae). Herpetol Notes 10: 439-441.

UETZ P, FREED P AND HOŠEK J. 2018. The Reptile Database, http://www.reptile-database.org, accessed 25 April 2018.

VAZ-FERREIRA R, ZOLESSI LC AND ACHAVAL F. 1970. Oviposición y desarollo de ofídios y lacertilios en hormigueros de Acromyrmex. Physis 29: 431-459.

VELASCO MA, ÚBEDA CA, WILLIAMS JD AND KACOLIRIS FP. 2017. Reproductive biology of the critically endangered Valcheta frog, Pleuroderma somuncurense (Anura: Leptodactylidae), from Patagonia, Argentina. South Am J Herpetol 12: 205-211.

VIEIRA EF. 1984. Rio Grande do Sul: geografia física e vegetação. Porto Alegre: Sagra, 184 p.

ZANELLAN AND CECHIN SZ. 2010. Reproductive biology of Echinanthera cyanopleura (Serpentes: Dipsadidae) in southern Brazil. Zoologia 27: 30-34.

\section{APPENDIX}

Species examined and vouchered in the herpetological collection of Universidade Federal do Rio Grande (CHFURG).

Philodryas aestiva - Brazil, Rio Grande do Sul: Capivari do Sul (CHFURG 1995); São José do Norte (CHFURG 1994, 2312, 2380); Rio Grande, Ilha da Torotama (CHFURG 5279, 5967), Ilha dos Marinheiros (CHFURG 4811), Ilha do Leonídeo (CHFURG 1721), Barra (CHFURG 1723, 1866, 1931, 1937, 1942, 1944, 1945, 1946, 1947, 1967, 1968, 1969, 1970, 1971, 1972, 1973, 1974, 1975, 1976, 1977, 2875, 2961, 3089, 3155, 3252, 3341, 3444, 4015, 4016, 4558, 4572, 4688, 4694, 4771, 4776, 4778, 4788, 4779, 4814, 4816, 4821, 4989, 5063, 5299, 5319, 5361, 5378, 5379, 5382, 5390, 5968), Área de Proteção Ambiental da Lagoa Verde
(CHFURG 1600, 1713, 1719, 2985, 3276, 5969), Senandes (CHFURG 3438), Área de Proteção Ambiental no5 (CHFURG 1705, 1706, 1707, 1708, $1709,1711,1712,1714,1715,1716,1717,1722$, 2984).

Philodryas patagoniensis - Brazil, Rio Grande do Sul: Cidreira (CHFURG 5448; 5579); Balneário Pinhal (CHFURG 5568); Palmares do Sul (CHFURG 2021, 2557); Pelotas, Laranjal (CHFURG 3750, 3751, 5478, 5508, 5509, 5510, 5512, 5513, 5518, 5519, 5520, 5573); São José do Norte (CHFURG 2004, 2017, 2382); Rio Grande, Ilha dos Marinheiros (CHFURG 1439), Barra (CHFURG 1696, 1825, 1864, 1927, 1943, 1978, 1979, 1980, 1981, 1982, 1986, 1987, 2014, 2971, 3097, 3203, 3205, 3206, 3209, 3374, 4568, 4559, 4768, 4772, 4774, 4775, 4777, 4780, 4906, 4987, 5056, 5211, 5278, 5512, 5280, 5298, 5320, 5589, 5973, 5974), Carreiros (CHFURG 803, 1307, 1434, 1489, 1718, 2019, 2818, 2835, 2874, 2910, 5449, 5970, 5971, 5972), Trevo (CHFURG 929), Palma (CHFURG 2395), Jardim do Sol (CHFURG 1984), Parque Marinha (CHFURG 901, 932), Parque São Pedro (CHFURG 866), Santa Rosa (CHFURG 836), Área de Proteção Ambiental da Lagoa Verde (CHFURG 1883, 1873, 1966, 2016, 2814, 3204, 3561), Área de Proteção Permanente $n^{\circ} 5$ (CHFURG 1875, 5975), Cassino (CHFURG 767, 1093, 1094, 1095, 1096, 1983, 1985, 5210, 5211, 5287, 5288, 5595), Querência (CHFURG 903, 904, 910, 911), Senandes (CHFURG 808, 928), Capilha (CHFURG 5444), Taim (CHFURG 1447, 2393 , 5445); Santa Vitória do Palmar (CHFURG 4443, 5563); Chuí (CHFURG 771, 3277, 4526, 5303, 5726). 